\title{
Allorecognition by T Lymphocytes and Allograft Rejection
}

\author{
Jose Marino, Joshua Paster and Gilles Benichou* \\ Center for Transplantation Sciences, Department of Surgery, Massachusetts General Hospital, Harvard Medical School, \\ Boston, MA, USA
}

Recognition of donor antigens by recipient $T$ cells in secondary lymphoid organs initiates the adaptive inflammatory immune response leading to the rejection of allogeneic transplants. Allospecific $\mathrm{T}$ cells become activated through interaction of their $\mathrm{T}$ cell receptors with intact allogeneic major histocompatibility complex $(\mathrm{MHC})$ molecules on donor cells (direct pathway) and/or donor peptides presented by self-MHC molecules on recipient antigen-presenting cells (APCs) (indirect pathway). In addition, recent studies show that alloreactive $T$ cells can also be stimulated through recognition of allogeneic $\mathrm{MHC}$ molecules displayed on recipient APCs (MHC cross-dressing) after their transfer via cell-cell contact or through extracellular vesicles (semi-direct pathway). The specific allorecognition pathway used by $T$ cells is dictated by intrinsic and extrinsic factors to the

\section{OPEN ACCESS}

Edited by:

Gilles Blancho,

University of Nantes, France

Reviewed by:

Thomas Wekerle,

Medical University of Vienna, Austria

Marcella Franquesa,

Institut d'Investigació Germans

Trias i Pujol, Spain

*Correspondence:

Gilles Benichou

gbenichou@partners.org

Specialty section:

This article was submitted to Alloimmunity and Transplantation,

a section of the journal

Frontiers in Immunology

Received: 15 September 2016

Accepted: 24 November 2016

Published: 14 December 2016

Citation:

Marino J, Paster J and Benichou G (2016) Allorecognition by

T Lymphocytes and

Allograft Rejection.

Front. Immunol. 7:582.

doi: 10.3389/fimmu.2016.00582 allograft and can influence the nature and magnitude of the alloresponse and rejection process. Consequently, various organs and tissues such as skin, cornea, and solid organ transplants are recognized differently by pro-inflammatory $T$ cells through these distinct pathways, which may explain why these grafts are rejected in a different fashion. On the other hand, the mechanisms by which anti-inflammatory regulatory T cells (Tregs) recognize alloantigen and promote transplantation tolerance are still unclear. It is likely that thymic Tregs are activated through indirect allorecognition, while peripheral Tregs recognize alloantigens in a direct fashion. As we gain insights into the mechanisms underlying allorecognition by pro-inflammatory and Treg cells, novel strategies are being designed to prevent allograft rejection in the absence of ongoing immunosuppressive drug treatment in patients.

\footnotetext{
Keywords: allorecognition, $\mathrm{T}$ cells, regulatory $\mathrm{T}$ cells, allograft rejection, $\mathrm{T}$ cell tolerance, major histocompatibility complex, exosomes
}

\section{INTRODUCTION}

Allorecognition relates to the detection of genetically encoded polymorphisms between individual organisms of the same species by the immune system. Allorecognition has been described in nearly all multicellular phyla, including invertebrates that are devoid of an adaptive immune system (1). Indeed, certain cells of the innate immune system such as NK cells and macrophages are capable of

Abbreviations: MHC, major histocompatibility complex; APC, antigen-presenting cell; Treg, regulatory T cell; tTreg, thymic regulatory cell; pTreg, peripheral regulatory T cell; $\gamma$ IFN, gamma interferon; TNF $\alpha$, tumor necrosis factor alpha; DST, donorspecific transfusion; DTR, diphtheria toxin receptor; TMEM, memory T cell; CTL, cytotoxic T lymphocyte; DC, dendritic cell. 
self-non-self discrimination $(2,3)$. In vertebrates, the adaptive immune response to allogeneic cells is initiated through recognition of polymorphic proteins by $\mathrm{T}$ lymphocytes through their antigen receptors. Subsequent activation of pro-inflammatory allospecific T cells initiates a cascade of reactions leading to rejection of transplanted allogeneic tissues and organs. Alternatively, under particular circumstances, deletion or inhibition of alloreactive effector T cells can result in allograft acceptance or tolerance $(4,5)$. In this article, we review current knowledge of the different pathways underlying alloantigen recognition by different $\mathrm{T}$ cells subsets and examine their contributions to rejection or tolerance of allografts.

\section{DIFFERENT MECHANISMS INVOLVED IN T CELL RECOGNITION OF ALLOANTIGENS}

The following section describes the three known pathways (direct, indirect, and semi-direct) by which recipient $\mathrm{T}$ cells recognize donor alloantigens [major histocompatibility complex (MHC) and minor antigens] after allotransplantation.

\section{Direct Allorecognition}

Seminal studies in skin-grafted rodents support the view that early after transplantation intra-graft dendritic cells (DCs) (passenger leukocytes) migrate through lymphatics to host regional lymph nodes (LNs) $(6,7)$. Naïve T cells located in these LNs become activated through recognition of allogeneic MHC molecules displayed on these donor passenger leukocytes (8). This phenomenon, known as direct $\mathrm{T}$ cell allorecognition, initiates an inflammatory immune response leading to rapid and acute cellular rejection of skin allografts (9). Unlike conventional $\mathrm{T}$ cell responses to nominal protein antigens, the direct $\mathrm{T}$ cell alloresponse is polyclonal in that it involves a large portion of the T cell repertoire (1-10\%) (10-13). Two non-mutually exclusive mechanisms have been proposed to explain this unique feature of the $\mathrm{T}$ cell response against allogeneic MHC molecules: the high determinant density and the multiple binary complex models (14-16). The high determinant density model postulates that each allogeneic MHC molecule on a foreign cell can be recognized by a single T cell receptor (TCR), which is focused on exposed amino acid polymorphisms of the allogeneic MHC molecule independent of the peptide bound to it. Likewise, various $\mathrm{T}$ cells may be activated even if each individual receptor on a given clone displays a low affinity for its ligand. The multiple binary complex model is based on the principle that each individual alloreactive $\mathrm{T}$ cell clone interacts with allogeneic $\mathrm{MHC}$ molecules bound to a defined peptide. Allo-MHC molecules being occupied by a multitude of different peptides can create many new $\mathrm{PMHC}$ complexes that can serve as ligands for various $\mathrm{T}$ cell clones. The prevalence of either model in $\mathrm{T}$ cell allorecognition presumably depends upon the degree of heterogeneity (structural and/or conformational) between recipient and donor MHC molecules. Unlike conventional immune responses, $\mathrm{T}$ cell responses to allogeneic $\mathrm{MHC}$ antigens can be observed in vitro with $\mathrm{T}$ cells isolated from naïve animals cultured with allogeneic irradiated cells. This so-called mixed allogeneic reaction [mixed lymphocyte reactions (MLR)] is believed to rely on the high frequency of precursor T cells capable of recognizing allogeneic MHC molecules. It is also possible, however, that the MLR may reflect the presence of alloreactive memory $\mathrm{T}$ cells generated after infections through cross-reactive recognition of self-MHC molecules bound to microbial peptides mimicking an allogeneic MHC-peptide complex, a phenomenon called heterologous immunity $(17,18)$. For instance, $\mathrm{T}$ cells from individuals sensitized to EBV peptides presented by self-MHC class I HLA-B8 also recognize the HLA-B4402 allogeneic MHC molecules (19). Consequently, HLA-B8 individuals display memory T cells directed to HLA-B4402 allogeneic subjects as a result of an EBV infection. The same phenomenon has also been shown in mice after exposure to LCMV and Leishmania parasites $(17,20,21)$.

\section{Indirect Allorecognition}

Seminal studies by Singer showed that allogeneic MHC class I antigens could be presented by self-MHC class I on antigen-presenting cells (APCs) and trigger the activation of some $\mathrm{CD}^{+}$cytotoxic $\mathrm{T}$ cells in vitro, a phenomenon referred to as cross-presentation (22). Most importantly, Lechler and Batchelor provided evidence for an alternative pathway of $\mathrm{T}$ cell alloresponse in vivo in the early 1980 s $(23,24)$. It was observed that allosensitization could occur in the absence of donor passenger leukocytes following retransplantation of kidney grafts in rats $(23,24)$. Based on the assumption that donor parenchymal cells were not capable of sensitizing naïve $\mathrm{T}$ cells, it was proposed that host $\mathrm{MHC}$ class $\mathrm{II}^{+}$bone marrow-derived professional APCs could present alloantigens and initiate an alloresponse. In 1992, our laboratory provided definitive evidence showing that allogeneic MHC peptides were regularly presented by self-MHC class II molecules on recipient APCs and triggered the activation of $\mathrm{CD} 4^{+} \mathrm{T}$ cells in the LNs of skin-grafted mice (25). The relevance of this process, called indirect allorecognition, in solid organ transplantation was documented the same year in two subsequent studies by Fabre and Suciu-Foca's groups in rats and humans, respectively $(26,27)$. Subsequent studies documented indirect activation of $\mathrm{CD}^{+} \mathrm{T}$ cells after skin transplantation; the relevance of this phenomenon in the rejection process is discussed later in this article (28-30). Determinant mapping and TCR repertoire studies showed that the initial indirect response to an allograft was oligoclonal and followed the rules of immunodominance in that it was mediated by a discrete set of $\mathrm{T}$ cell clones directed to a few dominant determinants usually located within polymorphic regions of allogeneic MHC proteins $(31,32)$. However, progressively, indirect alloresponse by $\mathrm{T}$ cells tend to spread to new formerly cryptic allo-MHC peptides (33). Cryptic determinants correspond to peptides that are not processed and/or presented efficiently enough to trigger a $\mathrm{T}$ cell response after protein immunization (34). However, $\mathrm{T}$ cell responses to these determinants can be elicited upon peptide immunization (34). Secondary responses to formerly cryptic determinants also called antigen spreading has been documented in autoimmune disorders $(35,36)$ and after allotransplantation and could be involved in chronic rejection (37). 
In addition to its role in allo-MHC recognition, indirect $\mathrm{T}$ cell recognition is considered as the main driving force being $\mathrm{T}$ cell responses to minor antigens $(\mathrm{mH})$, which are peptides usually derived from housekeeping proteins displaying some degree of polymorphism (38). The contributions of $\mathrm{mH}$ to the overall indirect alloresponse by $\mathrm{T}$ cells and to allograft rejection are discussed later in this article. Finally, it is important to note that it is still unclear where and through which process donor antigens are taken up and processed by recipient APCs and presented to T cells after transplantation. Acquisition of donor antigens by recipient APCs may occur in the graft itself or in the host lymphoid organs through pinocytosis of shed donor proteins, phagocytosis of dead donor cells and apoptotic bodies, or via transfer of donor antigens through cell-cell contact or phagocytosis of extracellular vesicles secreted by donor cells.

\section{Semi-Direct Allorecognition}

It is now well established that leukocytes exchange molecules, including RNA and proteins, either via cell-cell contact (trogocytosis), nanotubes, or through the release of extracellular vesicles such as exosomes (39-41). For instance, T cells were shown to acquire surface immunoglobulin molecules from B cells (42) and antigens from macrophages (43). Likewise, the transfer of MHC molecules between hematopoietic cells was originally documented by Frelinger et al. (44). Acquired peptide-MHC complexes have been shown to remain at the cell surface of APCs for more than $48 \mathrm{~h}$, providing ample opportunities for $\mathrm{T}$ cell activation (45). There is accumulating evidence suggesting that this process plays a key role in the initiation and regulation of immunity to microbes and tumors (46). Recent studies have documented the transfer of MHC class I and II molecules (MHC cross-dressing) between recipient and donor DCs after solid organ and bone marrow transplantation (40, $47,48)$. At the same time, DCs that have acquired allogeneic MHC proteins in vitro via cell-cell contact have been shown to stimulate allospecific T cells in vitro, through a mechanism often referred to as semi-direct allorecognition (Figure 1) (49-51). It is conceivable that allo-MHC cross-dressing of APCs after transplantation could occur via cell-cell contact and through secretion of extracellular vesicles. Lechler et al. have shown that DCs and endothelial cells can acquire MHC complexes in vitro and in vivo (after DC injections) through cell-cell contact in a temperature- and energy-dependent manner. In these studies, allo-MHC cross-dressed cells induced proliferation of Ag-specific T cells in vitro (49-51). On the other hand, a recent study by Marino in our laboratory shows that recipient APCs having acquired donor MHC from donor exosomes trafficking from skin and heart to host lymphoid organs are involved in $\mathrm{T}$ cell antigen recognition and activation after allotransplantation. Most exosomes expressed preferentially allogeneic MHC class II and were derived from donor DCs and B cells, i.e., bone marrow-derived professional APCs. However, it is important to note that a significant number of $\mathrm{MHC}$ class $\mathrm{II}^{+}$vesicles involved in MHC cross-dressing were not derived from these cells and could potentially be secreted by activated endothelial cells, as suggested by a previous report from Lechler's laboratory (50).
Altogether, these studies involving transfer of MHC antigens provide a different view of the process by which donor passenger leukocyte cells can trigger $\mathrm{T}$ cell alloresponses after transplantation. It is now crucial to investigate whether exosomes and allo-MHC cross-dressing are essential elements of the overall alloresponse and allograft rejection processes.

\section{RELATIONSHIPS BETWEEN DIFFERENT PATHWAYS}

Direct and indirect allorecognition represent distinct mechanisms involving different APCs, T cells, and antigen determinants. Each of these pathways can sufficiently and exclusively lead to acute rejection of fully allogeneic skin allografts (52). In certain circumstances, $\mathrm{T}$ cells activated directly and indirectly could either cooperate or suppress each other, a process influencing the survival of allografts. It is plausible that in recipients of MHC class I-disparate allografts, $\mathrm{CD}^{+} \mathrm{T}$ cells activated exclusively through indirect allorecognition provide help [via IL-2 and gamma interferon ( $\gamma$ IFN) secretion] for the direct activation of other $\mathrm{CD}^{+} \mathrm{T}$ cells (three-cell cluster model) or the differentiation of $\mathrm{CD}^{+}$cytotoxic $\mathrm{T}$ cells recognizing donor MHC class I peptides in a direct fashion (four-cell cluster model) (Figure 1). Likewise, in the absence of bone marrow-derived donor professional APCs, T cells recognizing donor MHC class I or II directly on parenchymal cells can receive costimulatory signals via interaction with CD80/86 or CD40 located on recipient professional APCs (activated through indirect presentation to T cells) (trans-costimulation) (Figure 1). At the same time, early inflammatory direct alloresponses associated with $\gamma$ IFN and tumor necrosis factor alpha production and subsequent induction of donor MHC class II expression on endothelial cells presumably enhances allo-MHC antigen processing by recipient APCs and indirect activation of $\mathrm{T}$ cells. Therefore, the direct and indirect alloresponses can act synergistically to reject an allograft.

\section{T CELL RECOGNITION PATHWAYS INVOLVED IN ALLOGRAFT REJECTION}

Many factors either intrinsic or extrinsic to the graft influence the nature and magnitude of the $\mathrm{T}$ cell response induced by a defined pathway of allorecognition. Consequently, the contribution of each $\mathrm{T}$ cell allorecognition pathway (direct or indirect) to the rejection process varies upon the nature of the tissue or organ transplanted, the site of the body where it is placed, and the immunological status of the recipient. This section describes some of the factors governing the initiation of direct and indirect alloresponses by $\mathrm{CD} 4^{+}$and $\mathrm{CD} 8^{+}$pro-inflammatory $\mathrm{T}$ cells and the rejection of allogeneic skin, corneal, and heart grafts.

\section{T Cell Allorecognition in Skin Transplantation}

Potent direct and indirect alloresponses by $\mathrm{CD} 4^{+} \mathrm{T}$ cells are induced after transplantation of fully MHC-mismatched skin allografts (13). The direct alloresponse to donor MHC class II antigens by inflammatory $\mathrm{CD} 4^{+} \mathrm{T}$ cells is polyclonal and leads 

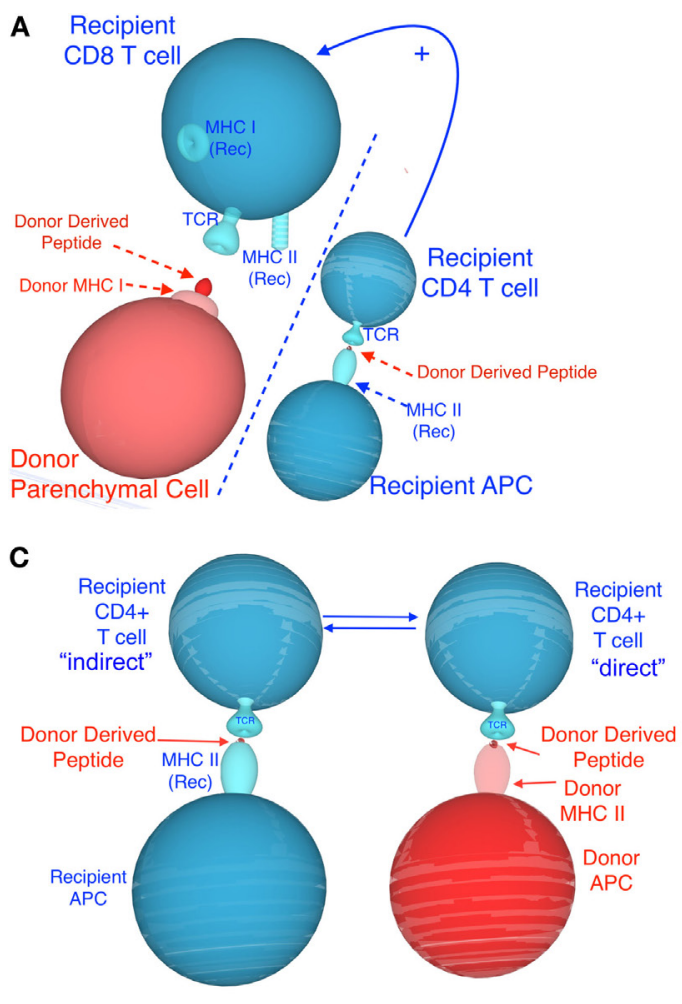
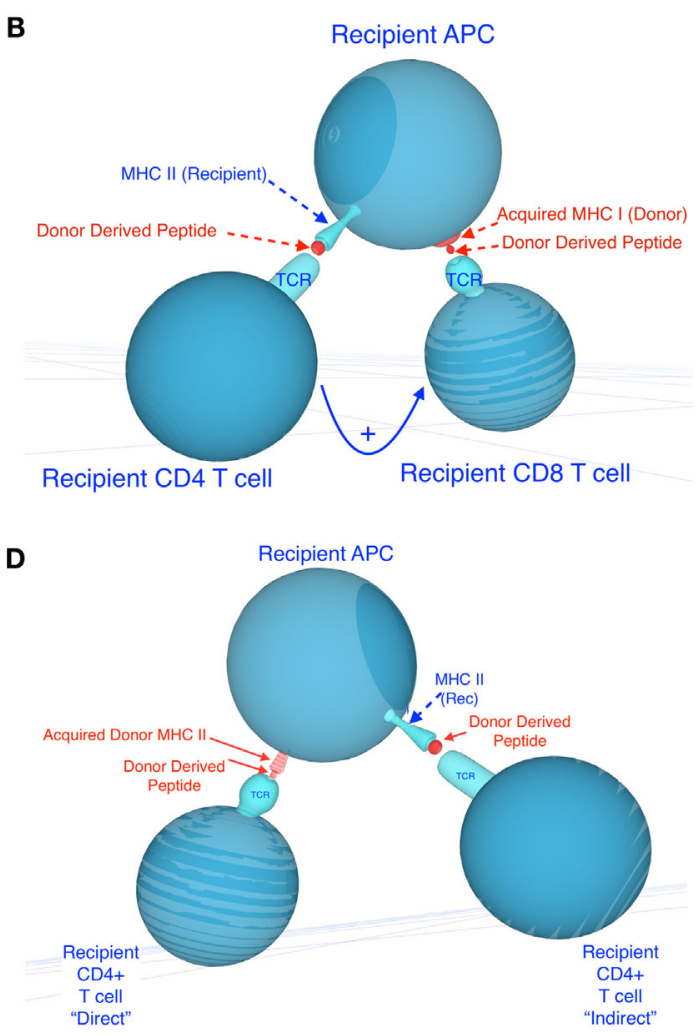

FIGURE 1 | Potential mechanisms involved in semi-direct allorecognition by recipient CD4+ and $\mathbf{C D 8}^{+} \mathbf{T}_{\mathbf{~ c e l l s}}$. Recipient cells are shown in blue and donor cells and peptides are shown in red. (A) depicts the classical four-cell cluster model in which CD4+ T cells activated indirectly [via recognition of recipient major histocompatibility complex $\left(\mathrm{MHC}\right.$ ) class $\mathrm{II}^{+}$donor peptide, displayed on recipient antigen-presenting cells (APCs)] may provide help for CD8 ${ }^{+} \mathrm{T}$ cells activated directly (via recognition of donor $\mathrm{MHC}$ class I on donor $\mathrm{APCs}$ ). (C) depicts the traditional four-cell cluster model in which $\mathrm{CD}^{+} \mathrm{T}^{+}$cells activated indirectly (via recognition of recipient $\mathrm{MHC}$ class $\mathrm{II}^{+}$donor peptide, displayed on recipient $\mathrm{APCS}$ ) and $\mathrm{CD} 4^{+} \mathrm{T}$ cells activated directly (via recognition of donor $\mathrm{MHC}$ class $\|$ on donor $\mathrm{APCs}$ ). (B,D) describe different mechanisms by which semi-direct allorecognition could allow for a three-cell cluster model in which different $T$ cells recognize different antigens on the same recipient APCs. This process would optimize T cell help by CD4+ ${ }^{+}$cells activated indirectly for CD8 ${ }^{+} \mathrm{T}$ cell activated directly (recognition of acquired MHC class I) (B) and enhance cooperation between CD4 ${ }^{+} \mathrm{T}$ cells activated directly (via recognition of acquired donor $\mathrm{MHC}$ class II) and indirectly (recipient MHC class II+ donor peptide) (D).

to the rapid rejection of skin allografts (53). Yet, studies from Auchincloss' laboratory using MHC class II-deficient skin allografts have demonstrated that the $\mathrm{CD}^{+} \mathrm{T}$ cell indirect alloresponse was sufficient on its own to cause acute skin graft rejection by providing help for the activation/differentiation of $\mathrm{CD}^{+}$cytotoxic $\mathrm{T}$ cells recognizing donor MHC class I directly $(54,55)$. This conclusion was further confirmed by experiments using recipient mice adoptively transferred with $\mathrm{CD}^{+} \mathrm{T}$ cell clones recognizing donor antigens indirectly (56). In addition, indirect responses by $\mathrm{CD}^{+} \mathrm{T}$ cells are also detectable after skin transplantation (28). Studies by Valujskikh and Heeger support the view that indirectly activated $\mathrm{CD}^{+} \mathrm{T}$ cells can reject skin allografts following recognition of self-MHC class $\mathrm{I}^{+}$allopeptides present on vascular endothelial cells after replacement of donor graft vessels by recipient ones $(30,57)$. Therefore, both $\mathrm{CD}^{+}$and $\mathrm{CD}^{+} \mathrm{T}$ cells activated directly and indirectly are elicited after skin grafting and can lead to acute rejection of these allografts. Recent articles by Marino et al. and Smyth et al. support the view that $\mathrm{T}$ cells activated through direct and possibly indirect pathway after skin transplantation recognize donor MHC molecules and peptides acquired and displayed by recipient APCs $(58,59)$. However, the precise contribution of this phenomenon to acute rejection of these grafts remains to be evaluated. Finally, it is important to note that skin allografts that are vascularized at the time of their placement are acutely rejected at the same pace as their conventional (non-primarily vascularized) counterparts, but they do not induce an indirect alloresponse (60). This shows that graft vascularization influences the nature of the allorecognition by $\mathrm{T}$ cells after skin transplantation.

\section{T Cell Allorecognition in Corneal Transplantation}

In contrast to skin transplants, corneal allograft rejection is slower and is driven by minor antigens instead of MHC disparities between the host and recipient (61). This unusual feature of corneal transplantation is attributed to the facts that (1) corneal 
allografts are devoid of $\mathrm{MHC}$ class $\mathrm{II}^{+}$APCs at the time of transplantation and (2) they are placed in the eye that is an immuneprivileged site of the body $(62,63)$. These grafts induce indirect but no direct alloresponses by $\mathrm{CD} 4^{+} \mathrm{T}$ cells, a feature presumably associated with the lack of donor MHC class II expression in the cornea (64). In addition, the indirect $\mathrm{CD} 4^{+} \mathrm{T}$ cell alloresponse is directed almost exclusively to minor antigens (61). Such dominance of minor antigens is likely to rely on the low expression of MHC antigens in the cornea [absence of MHC class II and reduced MHC class I expression (65)]. Additionally, in the absence of $\mathrm{CD}^{+} \mathrm{T}$ cell direct alloreactivity, indirect alloresponse may be biased toward $\mathrm{mH}$ antigens, as observed in the rejection of APC-depleted thyroid grafts (66). On the other hand, $\mathrm{CD}^{+}$ $\mathrm{T}$ cells activated directly against donor MHC class I are readily detected after corneal transplantation $(67,68)$. Although these $\mathrm{CD}^{+} \mathrm{T}$ cells produce $\gamma \mathrm{IFN}$, they do not display cytotoxic functions $(67,68)$.

Only indirectly activated $\mathrm{CD} 4^{+} \mathrm{T}$ cells then drive the rejection process. Interestingly, while no $\mathrm{MHC}$ class $\mathrm{II}^{+}$cells were originally detected in the cornea, studies by Dana's laboratory have documented the presence of DCs in the cervical LNs draining corneal allografts (69). Indeed, CD11c ${ }^{+}$DCs and $\mathrm{CD}_{1} 1 \mathrm{~b}^{+}$macrophages are present in the corneal epithelium (70). Interestingly, in "high-risk" recipients of corneal transplants placed in an inflamed eye bed environment (71), corneal DCs express MHC class II molecules as well as CD40, CD80, and CD86 co-receptors at the time of transplantation (71). Consequently, these allografts trigger vigorous direct alloresponses by host $\mathrm{CD}^{+} \mathrm{T}$ cells against intact donor MHC class II molecules and are acutely rejected in a few days similar to skin grafts (71). Therefore, lack of immunogenicity of corneal DCs is not an intrinsic property of these cells, but it is due to the microenvironment of the eye. This view is supported by Niederkorn's studies showing that heterotopic corneal allografts elicit bona fide cytotoxic T cell (CTL) responses (72). Likewise, we have shown that corneal allografts placed subcutaneously in mice trigger $\mathrm{CD}^{+} \mathrm{T}$ cell direct alloresponses (68). Altogether, these studies demonstrate that both intrinsic (APC contents) and extrinsic (site of placement) factors determine the fate of corneal allografts by influencing the allorecognition pathway and the nature of target alloantigens involved in the $\mathrm{T}$ cell response against these grafts.

\section{T Cell Allorecognition and Rejection of Vascularized Solid Organ Transplants}

Early acute rejection of cardiac and kidney allografts is essentially initiated by $\mathrm{CD} 4^{+} \mathrm{T}$ cells recognizing donor MHC class II molecules in a direct fashion $(73,74)$. These transplants differ from skin allografts in that they are vascularized at the time of their placement (75). This is associated with a rapid trafficking of graft DCs to the host spleen presumably occurring via reverse transendothelial vascular migration $(76,77)$. In addition, some studies suggest that these allografts could be rapidly infiltrated with recipient endogenous alloreactive effector memory $\mathrm{T}$ cells $(78,79)$. These pre-existing memory $\mathrm{T}$ cells are present at low frequencies (5-10\%) in laboratory rodents
$(80,81)$. In contrast, primates display much higher frequencies $(>50 \%)$ of alloreactive memory $\mathrm{T}$ cells before transplantation $(82,83)$. These memory $\mathrm{T}$ cells may be generated through mimicry with microbial antigens or prior exposure to allogeneic MHC molecules following events such as pregnancy or blood transfusion. We and others have shown that these memory $\mathrm{T}$ cells account for resistance to allograft tolerance induction in primates (82-85). Therefore, primarily naïve and presumably endogenous memory $T$ cells activated in a direct fashion mediate early acute rejection of solid organ transplants. Suppression of this response by calcineurin inhibitors and other immunosuppressive agents is regularly achieved in transplanted patients, thereby allowing large-scale clinical transplantation of organs such as kidneys and livers. However, many of these transplants are ultimately lost due to chronic rejection, a process associated with progressive graft tissue fibrosis and blood vessel occlusion $(86,87)$. There is strong circumstantial evidence suggesting that $\mathrm{T}$ cells activated indirectly are responsible for chronic allograft rejection, either on their own or through the induction of alloantibody production by B cells (86-89). The relevance of this concept in clinical transplantation is supported by the detection of donor HLA DR peptide-reactive T cells in kidneytransplanted patients with chronic rejection (90). Additionally, studies by Baker et al. showed the loss of direct and maintenance of indirect alloresponses in renal allograft recipients and its implications in chronic allograft nephropathy in patients (87). Finally, recent studies by Benichou and Morelli's laboratories suggest that activation of recipient $\mathrm{T}$ cells through semi-direct allorecognition might represent an essential element of the immune response to and rejection of cardiac allografts in mice $(58,91)$. Both studies show that $\mathrm{T}$ cells activated via this pathway recognized allo-MHC molecules transferred to recipient APCs by donor exosomes released either in the heart transplant or in the recipient's lymphoid organs $(58,91)$. Ongoing studies are underway to assess the role of semi-direct alloreactivity in acute and chronic rejection of heart and other solid organ transplants in animal models and patients.

\section{T CELL ALLORECOGNITION PATHWAYS IN REGULATORY TOLERANCE}

Allograft tolerance, defined as long-term survival of allogeneic transplants in the absence of ongoing immunosuppressive drug treatment, can occur via deletion or inhibition of alloreactive $\mathrm{T}$ cells. This process can occur naturally, as seen in the tolerance of paternal alloantigens expressed by the fetus during pregnancy $(92,93)$. In addition, immune-privileged tissues such as the central nervous system and the testis are tolerogenic in that they elicit systemic tolerance to foreign antigens to which they are exposed (94-96). Various cells and mediators of the innate and adaptive immune systems have been implicated in the process of allograft tolerance (4, 96-99). Among them, regulatory $\mathrm{T}$ cells (Tregs) play an essential role by suppressing inflammatory responses (100-102). Tregs are $\mathrm{CD} 4{ }^{+} \mathrm{CD} 25^{\text {high }} \mathrm{T}$ lymphocytes expressing FoxP3 transcription factor either constitutively (thymic Tregs or tTregs) or after 
peripheral recognition of antigens (peripheral Tregs or pTregs) $(100,103,104)$. In addition to their role in self-antigen tolerance, both Treg subsets can suppress inflammatory alloreactive $\mathrm{T}$ cells in vitro and in vivo. They inhibit alloreactivity in MLR in vitro $(4,96,99,105)$ and are thought to mediate transplant tolerance elicited via leukocyte costimulation blockade, donorspecific transfusion (4). This is supported by experiments in which inoculation of Tregs from tolerant mice to naive mice could prolong allograft survival and even transfer tolerance (4). In addition, studies from Colvin's laboratory using FoxP3diphtheria toxin receptor mice showed that in vivo deletion of Tregs abrogated ongoing tolerance to kidney allografts in mice (106). tTRegs are positively selected in the thymus medulla based on their high affinity for self-antigen pMHC complexes (107). While tTregs require TCR interaction with self-MHC class II molecules to mediate their suppress functions, they are thought to be non-antigen specific. Indeed, tTregs isolated from naïve mice can suppress $\mathrm{T}$ cells responding to polyclonal stimulators (anti-CD3/anti-CD28 mAbs or PMA/ionomycin) and MLR regardless of the nature of the allogeneic stimulators. The nature of the self-peptide determinants recognized for tTregs is not known. Studies from LeGuern's laboratory suggest that tTreg recognition is biased to self-MHC class II peptides bound with self-MHC class II molecules themselves (referred to as Tlo) (108). Tolerance of solid organ transplants in swine and rodents via allo-MHC class II transgenesis support this view (109-113). In contrast to tTregs, pTregs presumably acquire FoxP3 expression and suppressor functions through recognition of donor antigens ( $\mathrm{MHC}$ and/or minor antigens) presented by selected APCs (immature DCs and plasmocytoid DCs) in an appropriate cytokine milieu (4, 114-117). Although activation of pTregs may be antigen specific, it is not clear whether their suppressive function follows the same rules. Therefore, both Treg subsets involved in allograft tolerance are presumably activated through recognition of peptides presented by self-MHC class II on recipient APCs, i.e., in an indirect fashion. However, the mechanisms by which they suppress alloreactive $\mathrm{T}$ cells and induce and/or maintain allograft tolerance are still unknown.

\section{REFERENCES}

1. Rosa SF, Powell AE, Rosengarten RD, Nicotra ML, Moreno MA, Grimwood $\mathrm{J}$, et al. Hydractinia allodeterminant alr1 resides in an immunoglobulin superfamily-like gene complex. Curr Biol (2010) 20(12):1122-7. doi:10.1016/ j.cub.2010.04.050

2. Kroemer A, Edtinger K, Li XC. The innate natural killer cells in transplant rejection and tolerance induction. Curr Opin Organ Transplant (2008) 13(4):339-43. doi:10.1097/MOT.0b013e3283061115

3. Oberbarnscheidt MH, Zecher D, Lakkis FG. The innate immune system in transplantation. Semin Immunol (2011) 23(4):264-72. doi:10.1016/ j.smim.2011.06.006

4. Wood KJ, Sakaguchi S. Regulatory T cells in transplantation tolerance. Nat Rev Immunol (2003) 3(3):199-210. doi:10.1038/nri1027

5. Wekerle T, Kurtz J, Bigenzahn S, Takeuchi Y, Sykes M. Mechanisms of transplant tolerance induction using costimulatory blockade. Curr Opin Immunol (2002) 14(5):592-600. doi:10.1016/S0952-7915(02)00378-3

6. Barker CF, Billingham RE. The role of afferent lymphatics in the rejection of skin homografts. J Exp Med (1968) 128(1):197-221. doi:10.1084/ jem.128.1.197

\section{CONCLUDING REMARKS}

It is now firmly established that the mechanisms by which $\mathrm{T}$ cell recognize and respond to alloantigens greatly vary upon the nature of the transplanted organ or tissue, the site of anatomical placement, and the immunological status of the host. This explains why certain transplants, such as skin allografts, which induce potent inflammatory responses by both $\mathrm{CD} 4^{+}$and $\mathrm{CD} 8^{+}$, activated directly and indirectly, are highly immunogenic and thereby resistant to tolerance induction. In contrast, corneal allografts that elicit only indirect alloresponses by $\mathrm{CD} 4^{+} \mathrm{T}$ cells are tolerogenic and often spontaneously accepted. On the other hand, early acute rejection of solid organ allografts such as hearts and kidneys is mediated essentially by $\mathrm{T}$ cells activated directly. While this immune response results in a potent inflammatory reaction, it is readily inhibited by calcineurin inhibitors. This explains why these drugs have been effective at achieving prolonged survival of organ allografts in patients. These treatments do not, however, efficiently suppress alloreactive memory $\mathrm{T}$ cells, thus precluding transplantation in patients sensitized to their potential donors (10\% of patients). Most importantly, many transplanted organs are progressively lost due to chronic rejection, a process presumably initiated by indirectly activated $\mathrm{T}$ cells and subsequent production of cytotoxic anti-donor antibodies. For reasons that are still unclear, this response is not always efficiently suppressed by current immunosuppressive drugs. Therefore, future challenges in clinical transplantation will be to suppress or eliminate allospecific memory $\mathrm{T}$ cells and to prevent the development of indirect alloresponses.

\section{AUTHOR CONTRIBUTIONS}

All the authors listed have made substantial, direct, and intellectual contribution to the work and approved it for publication.

\section{FUNDING}

This study was supported by NIH grants R21AI111191 and R21AI117466 to Dr. GB.

7. Steinmuller D. Passenger leukocytes and the immunogenicity of skin allografts. J Invest Dermatol (1980) 75(1):107-15. doi:10.1111/1523-1747. ep12521331

8. Billingham RE. The passenger cell concept in transplantation immunology. Cell Immunol (1971) 2(1):1-12. doi:10.1016/0008-8749(71)90022-0

9. Rosenberg AS, Singer A. Cellular basis of skin allograft rejection: an in vivo model of immune-mediated tissue destruction. Annu Rev Immunol (1992) 10:333-58. doi:10.1146/annurev.iy.10.040192.002001

10. Lindahl KF, Wilson DB. Histocompatibility antigen-activated cytotoxic T lymphocytes. II. Estimates of the frequency and specificity of precursors. J Exp Med (1977) 145(3):508-22. doi:10.1084/jem.145.3.508

11. Ashwell JD, Chen C, Schwartz RH. High frequency and nonrandom distribution of alloreactivity in $\mathrm{T}$ cell clones selected for recognition of foreign antigen in association with self class II molecules. J Immunol (1986) 136(2):389-95.

12. Suchin EJ, Langmuir PB, Palmer E, Sayegh MH, Wells AD, Turka LA. Quantifying the frequency of alloreactive T cells in vivo: new answers to an old question. J Immunol (2001) 166(2):973-81. doi:10.4049/jimmunol.166.2.973

13. Benichou G, Valujskikh A, Heeger PS. Contributions of direct and indirect $\mathrm{T}$ cell alloreactivity during allograft rejection in mice. J Immunol (1999) 162(1):352-8 
14. Rogers NJ, Lechler RI. Allorecognition. Am J Transplant (2001) 1(2):97-102. doi:10.1034/j.1600-6143.2001.10201.x

15. Lechler RI, Lombardi G, Batchelor JR, Reinsmoen N, Bach FH. The molecular basis of alloreactivity. Immunol Today (1990) 11(3):83-8. doi:10.1016/0167-5699(90)90033-6

16. Hogquist KA, Jameson SC, Heath WR, Howard JL, Bevan MJ, Carbone FR. $\mathrm{T}$ cell receptor antagonist peptides induce positive selection. Cell (1994) 76(1):17-27. doi:10.1016/0092-8674(94)90169-4

17. Adams AB, Pearson TC, Larsen CP. Heterologous immunity: an overlooked barrier to tolerance. Immunol Rev (2003) 196:147-60. doi:10.1046/j.1600-065X.2003.00082.x

18. Taylor DK, Neujahr D, Turka LA. Heterologous immunity and homeostatic proliferation as barriers to tolerance. Curr Opin Immunol (2004) 16(5):558-64. doi:10.1016/j.coi.2004.07.007

19. Amir AL, D’Orsogna LJ, Roelen DL, van Loenen MM, Hagedoorn RS, de Boer R, et al. Allo-HLA reactivity of virus-specific memory T cells is common. Blood (2010) 115(15):3146-57. doi:10.1182/blood-2009-07-234906

20. Brehm MA, Markees TG, Daniels KA, Greiner DL, Rossini AA, Welsh RM. Direct visualization of cross-reactive effector and memory allo-specific CD8 T cells generated in response to viral infections. JImmunol (2003) 170(8):4077-86. doi:10.4049/jimmunol.170.8.4077

21. Pantenburg B, Heinzel F, Das L, Heeger PS, Valujskikh A. T cells primed by Leishmania major infection cross-react with alloantigens and alter the course of allograft rejection. J Immunol (2002) 169(7):3686-93. doi:10.4049/ jimmunol.169.7.3686

22. Golding H, Singer A. Role of accessory cell processing and presentation of shed $\mathrm{H}-2$ alloantigens in allospecific cytotoxic $\mathrm{T}$ lymphocyte responses. J Immunol (1984) 133(2):597-605.

23. Lechler RI, Batchelor JR. Immunogenicity of retransplanted rat kidney allografts. Effect of inducing chimerism in the first recipient and quantitative studies on immunosuppression of the second recipient. J Exp Med (1982) 156(6):1835-41. doi:10.1084/jem.156.6.1835

24. Lechler RI, Batchelor JR. Restoration of immunogenicity to passenger cell-depleted kidney allografts by the addition of donor strain dendritic cells. J Exp Med (1982) 155(1):31-41. doi:10.1084/jem.155.1.31

25. Benichou G, Takizawa PA, Ho PT, Killion CC, Olson CA, McMillan M, et al. Immunogenicity and tolerogenicity of self-major histocompatibility complex peptides. J Exp Med (1990) 172(5):1341-6. doi:10.1084/jem.172.5.1341

26. Liu Z, Braunstein NS, Suciu-Foca N. T cell recognition of allopeptides in context of syngeneic MHC. J Immunol (1992) 148(1):35-40.

27. Fangmann J, Dalchau R, Sawyer GJ, Priestley CA, Fabre JW. T cell recognition of donor major histocompatibility complex class I peptides during allograft rejection. Eur J Immunol (1992) 22(6):1525-30. doi:10.1002/eji.1830220627

28. Popov IA, Fedoseyeva EV, Orr PL, Garovoy MR, Benichou G. Direct evidence for in vivo induction of CD8+ cytotoxic T cells directed to donor MHC class I peptides following mouse allotransplantation. Transplantation (1995) 60(12):1621-4.

29. Valujskikh A, Hartig C, Heeger PS. Indirectly primed CD8+ T cells are a prominent component of the allogeneic T-cell repertoire after skin graft rejection in mice. Transplantation (2001) 71(3):418-21. doi:10.1097/00007890-200102150-00014

30. Valujskikh A, Lantz O, Celli S, Matzinger P, Heeger PS. Cross-primed CD8(+) $\mathrm{T}$ cells mediate graft rejection via a distinct effector pathway. Nat Immunol (2002) 3(9):844-51. doi:10.1038/ni831

31. Benichou G, Fedoseyeva E, Lehmann PV, Olson CA, Geysen HM, McMillan M, et al. Limited T cell response to donor MHC peptides during allograft rejection. Implications for selective immune therapy in transplantation. J Immunol (1994) 153(3):938-45.

32. Liu Z, Sun YK, Xi XYP, Hong B, Harris PE, Reed EF, et al. Limited usage of $\mathrm{T}$ cell receptor $\mathrm{V}$ beta genes by allopeptide-specific $\mathrm{T}$ cells. J Immunol (1993) 150(8 Pt 1):3180-6.

33. Boisgerault F, Anosova NG, Tam RC, Illigens BM, Fedoseyeva EV, Benichou G. Induction of T-cell response to cryptic MHC determinants during allograft rejection. Hum Immunol (2000) 61(12):1352-62. doi:10.1016/ S0198-8859(00)00209-3

34. Sercarz EE, Lehmann PV, Ametani A, Benichou G, Miller A, Moudgil K. Dominance and crypticity of T cell antigenic determinants. Annu Rev Immunol (1993) 11:729-66. doi:10.1146/annurev.iy.11.040193.003501
35. Lehmann PV, Forsthuber T, Miller A, Sercarz EE. Spreading of T-cell autoimmunity to cryptic determinants of an autoantigen. Nature (1992) 358(6382):155-7. doi:10.1038/358155a0

36. Lehmann PV, Sercarz EE, Forsthuber T, Dayan CM, Gammon G. Determinant spreading and the dynamics of the autoimmune T-cell repertoire [see comments]. Immunol Today (1993) 14(5):203-8. doi:10.1016/ 0167-5699(93)90163-F

37. Suciu-Foca N, Harris PE, Cortesini R. Intramolecular and intermolecular spreading during the course of organ allograft rejection. Immunol Rev (1998) 164:241-6. doi:10.1111/j.1600-065X.1998.tb01224.x

38. Goulmy E. Human minor histocompatibility antigens. Curr Opin Immunol (1996) 8(1):75-81. doi:10.1016/S0952-7915(96)80108-7

39. Joly E, Hudrisier D. What is trogocytosis and what is its purpose? Nat Immunol (2003) 4(9):815. doi:10.1038/ni0903-815

40. Brown K, Sacks SH, Wong W. Extensive and bidirectional transfer of major histocompatibility complex class II molecules between donor and recipient cells in vivo following solid organ transplantation. FASEB J (2008) 22(11):3776-84. doi:10.1096/fj.08-107441

41. Thery C, Zitvogel L, Amigorena S. Exosomes: composition, biogenesis and function. Nat Rev Immunol (2002) 2(8):569-79. doi:10.1038/nri855

42. Hudson L, Sprent J. Specific adsorption of IgM antibody onto H-2-activated mouse T lymphocytes. JExp Med (1976) 143(2):444-9. doi:10.1084/ jem.143.2.444

43. Bona C, Robineaux R, Anteunis A, Heuclin C, Astesano A. Transfer of antigen from macrophages to lymphocytes. II. Immunological significance of the transfer of lipopolysaccharide. Immunology (1973) 24(5):831-40.

44. Frelinger JA, Neiderhuber JE, David CS, Shreffler DC. Evidence for the expression of Ia (H-2-associated) antigens on thymus-derived lymphocytes. J Exp Med (1974) 140(5):1273-84. doi:10.1084/jem.140.5.1273

45. Dolan BP, Gibbs KD Jr, Ostrand-Rosenberg S. Dendritic cells cross-dressed with peptide MHC class I complexes prime CD8+ T cells. J Immunol (2006) 177(9):6018-24. doi:10.4049/jimmunol.177.9.6018

46. Brown K, Fidanboylu M, Wong W. Intercellular exchange of surface molecules and its physiological relevance. Arch Immunol Ther Exp (Warsz) (2010) 58(4):263-72. doi:10.1007/s00005-010-0085-y

47. Harper SJ, Ali JM, Wlodek E, Negus MC, Harper IG, Chhabra M, et al. CD8 T-cell recognition of acquired alloantigen promotes acute allograft rejection. Proc Natl Acad Sci U S A (2015) 112(41):12788-93. doi:10.1073/ pnas. 1513533112

48. Markey KA, Koyama M, Gartlan KH, Leveque L, Kuns RD, Lineburg KE, et al. Cross-dressing by donor dendritic cells after allogeneic bone marrow transplantation contributes to formation of the immunological synapse and maximizes responses to indirectly presented antigen. J Immunol (2014) 192(11):5426-33. doi:10.4049/jimmunol.1302490

49. Herrera OB, Golshayan D, Tibbott R, Salcido Ochoa F, James MJ, Marelli-Berg FM, et al. A novel pathway of alloantigen presentation by dendritic cells. J Immunol (2004) 173(8):4828-37. doi:10.4049/jimmunol. 173.8.4828

50. Smyth LA, Herrera OB, Golshayan D, Lombardi G, Lechler RI. A novel pathway of antigen presentation by dendritic and endothelial cells: implications for allorecognition and infectious diseases. Transplantation (2006) 82(1 Suppl):S15-8. doi:10.1097/01.tp.0000231347.06149.ca

51. Russo V, Zhou D, Sartirana C, Rovere P, Villa A, Rossini S, et al. Acquisition of intact allogeneic human leukocyte antigen molecules by human dendritic cells. Blood (2000) 95(11):3473-7.

52. Benichou G, Yamada Y, Yun SH, Lin C, Fray M, Tocco G. Immune recognition and rejection of allogeneic skin grafts. Immunotherapy (2011) 3(6):757-70. doi:10.2217/imt.11.2

53. Benichou G. Direct and indirect antigen recognition: the pathways to allograft immune rejection. Front Biosci (1999) 4:D476-80. doi:10.2741/A442

54. Auchincloss H Jr, Lee R, Shea S, Markowitz JS, Grusby MJ, Glimcher LH. The role of "indirect" recognition in initiating rejection of skin grafts from major histocompatibility complex class II-deficient mice. Proc Natl Acad Sci U S A (1993) 90(8):3373-7. doi:10.1073/pnas.90.8.3373

55. Lee RS, Grusby MJ, Glimcher LH, Winn HJ, Auchincloss H Jr. Indirect recognition by helper cells can induce donor-specific cytotoxic T lymphocytes in vivo. JExp Med (1994) 179(3):865-72. doi:10.1084/jem. 179.3.865 
56. Valujskikh A, Heeger PS. CD4+ T cells responsive through the indirect pathway can mediate skin graft rejection in the absence of interferon-gamma. Transplantation (2000) 69(5):1016-9. doi:10.1097/ 00007890-200003150-00063

57. Valujskikh A, VanBuskirk AM, Orosz CG, Heeger PS. A role for TGFbeta and $\mathrm{B}$ cells in immunologic tolerance after intravenous injection of soluble antigen. Transplantation (2001) 72(4):685-93. doi:10.1097/ 00007890-200108270-00022

58. Marino J, Babiker M, Crosby Bertorini P, Paster JT, LeGuern C, Germana S, et al. Donor exosomes rather than passenger leukocytes initiate alloreactive $\mathrm{T}$ cell responses after transplantation. Sci Immunol (2016) 1(1):1-12. doi:10.1126/sciimmunol.aaf8759

59. Smyth LA, Lechler RI, Lombardi G. Continuous acquisition of MHC:peptide complexes by recipient cells contributes to the generation of anti-graft CD8+ T cell immunity. Am J Transplant (2016) 16(11):1-9. doi:10.1111/ajt.13996

60. Kant CD, Akiyama Y, Tanaka K, Shea S, Connolly SE, Germana S, et al. Primary vascularization of allografts governs their immunogenicity and susceptibility to tolerogenesis. J Immunol (2013) 191(4):1948-56. doi:10.4049/ jimmunol.1202092

61. Sano Y, Ksander BR, Streilein JW. Minor H, rather than MHC, alloantigens offer the greater barrier to successful orthotopic corneal transplantation in mice. Transpl Immunol (1996) 4(1):53-6. doi:10.1016/S0966-3274(96)80035-9

62. Streilein JW. Immunologic privilege of the eye. Springer Semin Immunopathol (1999) 21(2):95-111. doi:10.1007/BF00810243

63. Streilein JW, Wilbanks GA, Cousins SW. Immunoregulatory mechanisms of the eye. J Neuroimmunol (1992) 39(3):185-200. doi:10.1016/ 0165-5728(92) $90253-\mathrm{H}$

64. Streilein JW, Toews GB, Bergstresser PR. Corneal allografts fail to express Ia antigens. Nature (1979) 282(5736):326-7. doi:10.1038/282326a0

65. Whitsett CF, Stulting RD. The distribution of HLA antigens on human corneal tissue. Invest Ophthalmol Vis Sci (1984) 25(5):519-24.

66. Bartlett ST, Jennings AS, Yu C, Naji A, Barker CF, Silvers WK. Influence of culturing on the survival of major histocompatibility complex-compatible and -incompatible thyroid grafts in rats. J Exp Med (1983) 157(1):348-52. doi:10.1084/jem.157.1.348

67. Boisgerault F, Liu Y, Anosova N, Ehrlich E, Dana MR, Benichou G. Role of $\mathrm{CD} 4+$ and $\mathrm{CD} 8+\mathrm{T}$ cells in allorecognition: lessons from corneal transplantation. J Immunol (2001) 167(4):1891-9. doi:10.4049/jimmunol. 167.4.1891

68. Boisgerault F, Liu Y, Anosova N, Dana R, Benichou G. Differential roles of direct and indirect allorecognition pathways in the rejection of skin and corneal transplants. Transplantation (2009) 87(1):16-23. doi:10.1097/ TP.0b013e318191b38b

69. Liu Y, Hamrah P, Zhang Q, Taylor AW, Dana MR. Draining lymph nodes of corneal transplant hosts exhibit evidence for donor major histocompatibility complex (MHC) class II-positive dendritic cells derived from MHC class II-negative grafts. J Exp Med (2002) 195(2):259-68. doi:10.1084/ jem. 20010838

70. Hamrah P, Liu Y, Zhang Q, Dana MR. The corneal stroma is endowed with a significant number of resident dendritic cells. Invest Ophthalmol Vis Sci (2003) 44(2):581-9. doi:10.1167/iovs.02-0838

71. Huq S, Liu Y, Benichou G, Dana MR. Relevance of the direct pathway of sensitization in corneal transplantation is dictated by the graft bed microenvironment. J Immunol (2004) 173(7):4464-9. doi:10.4049/jimmunol.173. 7.4464

72. Matoba AY, Peeler JS, Niederkorn JY. T cell subsets in the immune rejection of murine heterotopic corneal allografts. Invest Ophthalmol Vis Sci (1986) 27(8):1244-54.

73. Krieger NR, Yin DP, Fathman CG. CD4+ but not CD8+ cells are essential for allorejection. J Exp Med (1996) 184(5):2013-8. doi:10.1084/jem.184.5.2013

74. Trager DK, Banks BA, Rosenbaum GE, Holm BI, Shizuru JA, Strober $\mathrm{S}$, et al. Cardiac allograft prolongation in mice treated with combined posttransplantation total-lymphoid irradiation and anti-L3T4 antibody therapy. Transplantation (1989) 47(4):587-91. doi:10.1097/ 00007890-198904000-00004

75. CorryRJ,WinnHJ,RussellPS.Primarilyvascularizedallograftsofheartsinmice. The role of $\mathrm{H}-2 \mathrm{D}, \mathrm{H}-2 \mathrm{~K}$, and non- $\mathrm{H}-2$ antigens in rejection. Transplantation (1973) 16(4):343-50. doi:10.1097/00007890-197310000-00010
76. Larsen CP, Morris PJ, Austyn JM. Migration of dendritic leukocytes from cardiac allografts into host spleens. A novel pathway for initiation of rejection. J Exp Med (1990) 171(1):307-14. doi:10.1084/jem.171.1.307

77. Wang Z, Castellaneta A, De Creus A, Shufesky WJ, Morelli AE, Thomson AW. Heart, but not skin, allografts from donors lacking Flt3 ligand exhibit markedly prolonged survival time. JImmunol (2004) 172(10):5924-30. doi:10.4049/jimmunol.172.10.5924

78. Su CA, Iida S, Abe T, Fairchild RL. Endogenous memory CD8 T cells directly mediate cardiac allograft rejection. Am J Transplant (2014) 14(3):568-79. doi:10.1111/ajt.12605

79. Obhrai JS, Oberbarnscheidt MH, Hand TW, Diggs L, Chalasani G, Lakkis FG. Effector $\mathrm{T}$ cell differentiation and memory $\mathrm{T}$ cell maintenance outside secondary lymphoid organs. J Immunol (2006) 176(7):4051-8. doi:10.4049/ jimmunol.176.7.4051

80. Adams AB, Williams MA, Jones TR, Shirasugi N, Durham MM, Kaech SM, et al. Heterologous immunity provides a potent barrier to transplantation tolerance. J Clin Invest (2003) 111(12):1887-95. doi:10.1172/JCI200317477

81. Valujskikh A, Lakkis FG. In remembrance of things past: memory $\mathrm{T}$ cells and transplant rejection. Immunol Rev (2003) 196:65-74. doi:10.1046/j.1600-065X.2003.00087.x

82. Nadazdin O, Boskovic S, Murakami T, O'Connor DH, Wiseman RW, Karl JA, et al. Phenotype, distribution and alloreactive properties of memory T cells from cynomolgus monkeys. Am J Transplant (2010) 10(6):1375-84. doi:10.1111/j.1600-6143.2010.03119.x

83. Nadazdin O, Boskovic S, Murakami T, Tocco G, Smith RN, Colvin RB, et al. Host alloreactive memory $\mathrm{T}$ cells influence tolerance to kidney allografts in nonhuman primates. Sci Transl Med (2011) 3(86):86ra51. doi:10.1126/ scitranslmed.3002093

84. Heeger PS, Greenspan NS, Kuhlenschmidt S, Dejelo C, Hricik DE, Schulak JA, et al. Pretransplant frequency of donor-specific, IFN-gamma-producing lymphocytes is a manifestation of immunologic memory and correlates with the risk of posttransplant rejection episodes. J Immunol (1999) 163(4):2267-75.

85. Hricik DE, Rodriguez V, Riley J, Bryan K, Tary-Lehmann M, Greenspan N, et al. Enzyme linked immunosorbent spot (ELISPOT) assay for interferongamma independently predicts renal function in kidney transplant recipients. Am J Transplant (2003) 3(7):878-84. doi:10.1034/j.1600-6143. 2003.00132.x

86. Lee RS, Yamada K, Houser SL, Womer KL, Maloney ME, Rose HS, et al. Indirect recognition of allopeptides promotes the development of cardiac allograft vasculopathy. Proc Natl Acad Sci U S A (2001) 98(6):3276-81. doi:10.1073/pnas. 051584498

87. Baker RJ, Hernandez-Fuentes MP, Brookes PA, Chaudhry AN, Cook HT, Lechler RI. Loss of direct and maintenance of indirect alloresponses in renal allograft recipients: implications for the pathogenesis of chronic allograft nephropathy. J Immunol (2001) 167(12):7199-206. doi:10.4049/ jimmunol.167.12.7199

88. Hornick PI, Mason PD, Baker RJ, Hernandez-Fuentes M, Frasca L, Lombardi $\mathrm{G}$, et al. Significant frequencies of T cells with indirect anti-donor specificity in heart graft recipients with chronic rejection. Circulation (2000) 101(20):2405-10. doi:10.1161/01.CIR.101.20.2405

89. Suciu-Foca N, Liu Z, Colovai AI, Tugulea S, Reed EF, Mancini D, et al. Role of indirect allorecognition in chronic rejection of human allografts. Transplant Proc (1996) 28(1):404-5.

90. Najafian N, Salama AD, Fedoseyeva EV, Benichou G, Sayegh MH. Enzymelinked immunosorbent spot assay analysis of peripheral blood lymphocyte reactivity to donor HLA-DR peptides: potential novel assay for prediction of outcomes for renal transplant recipients. JAm Soc Nephrol (2002) 13(1):252-9.

91. Liu Q, Rojas-Canales DM, Divito SJ, Shufesky WJ, Stolz DB, Erdos G, et al. Donor dendritic cell-derived exosomes promote allograft-targeting immune response. J Clin Invest (2016) 126(8):2805-20. doi:10.1172/JCI84577

92. Vacchio MS, Jiang SP. The fetus and the maternal immune system: pregnancy as a model to study peripheral T-cell tolerance. Crit Rev Immunol (1999) 19(5-6):461-80.

93. Ait-Azzouzene D, Gendron MC, Houdayer M, Langkopf A, Burki K, Nemazee D, et al. Maternal B lymphocytes specific for paternal histocompatibility antigens are partially deleted during pregnancy. J Immunol (1998) 161(6):2677-83. 
94. Niederkorn JY. Immune privilege and immune regulation in the eye. $A d v$ Immunol (1990) 48:191-226. doi:10.1016/S0065-2776(08)60755-5

95. Nasr IW, Wang Y, Gao G, Deng S, Diggs L, Rothstein DM, et al. Testicular immune privilege promotes transplantation tolerance by altering the balance between memory and regulatory T cells. J Immunol (2005) 174(10):6161-8. doi:10.4049/jimmunol.174.10.6161

96. Cobbold SP, Adams E, Graca L, Daley S, Yates S, Paterson A, et al. Immune privilege induced by regulatory $\mathrm{T}$ cells in transplantation tolerance. Immunol Rev (2006) 213:239-55. doi:10.1111/j.1600-065X.2006. 00428.x

97. Wekerle T, Kurtz J, Sayegh M, Ito H, Wells A, Bensinger S, et al. Peripheral deletion after bone marrow transplantation with costimulatory blockade has features of both activation-induced cell death and passive cell death. J Immunol (2001) 166(4):2311-6. doi:10.4049/jimmunol.166.4.2311

98. LaRosa DF, Rahman AH, Turka LA. The innate immune system in allograft rejection and tolerance. JImmunol (2007) 178(12):7503-9. doi:10.4049/ jimmunol.178.12.7503

99. Waldmann H, Graca L, Cobbold S, Adams E, Tone M, Tone Y. Regulatory $\mathrm{T}$ cells and organ transplantation. Semin Immunol (2004) 16(2):119-26. doi:10.1016/j.smim.2003.12.007

100. Sakaguchi S, Yamaguchi T, Nomura T, Ono M. Regulatory T cells and immune tolerance. Cell (2008) 133(5):775-87. doi:10.1016/j.cell.2008. 05.009

101. Sakaguchi S, Miyara M, Costantino CM, Hafler DA. FOXP3+ regulatory T cells in the human immune system. Nat Rev Immunol (2010) 10(7):490-500. doi:10.1038/nri2785

102. Shevach EM, McHugh RS, Piccirillo CA, Thornton AM. Control of T-cell activation by CD4+ CD25+ suppressor T cells. Immunol Rev (2001) 182:58-67. doi:10.1034/j.1600-065X.2001.1820104.X

103. Sakaguchi S, Sakaguchi N, Shimizu J, Yamazaki S, Sakihama T, Itoh M, et al. Immunologic tolerance maintained by $\mathrm{CD} 25+\mathrm{CD} 4+$ regulatory $\mathrm{T}$ cells: their common role in controlling autoimmunity, tumor immunity, and transplantation tolerance. Immunol Rev (2001) 182:18-32. doi:10.1034/j.1600-065X.2001.1820102.x

104. Shevach EM, McHugh RS, Thornton AM, Piccirillo C, Natarajan K, Margulies DH. Control of autoimmunity by regulatory T cells. Adv Exp Med Biol (2001) 490:21-32. doi:10.1007/978-1-4615-1243-1_3

105. Graca L, Cobbold SP, Waldmann H. Identification of regulatory $\mathrm{T}$ cells in tolerated allografts. J Exp Med (2002) 195(12):1641-6. doi:10.1084/ jem.20012097

106. Miyajima M, Chase CM, Alessandrini A, Farkash EA, Della Pelle P, Benichou G, et al. Early acceptance of renal allografts in mice is dependent on foxp3(+) cells. Am J Pathol (2011) 178(4):1635-45. doi:10.1016/j.ajpath. 2010.12.024
107. Josefowicz SZ, Rudensky A. Control of regulatory T cell lineage commitment and maintenance. Immunity (2009) 30(5):616-25. doi:10.1016/ j.immuni.2009.04.009

108. LeGuern C. Regulation of T-cell functions by MHC class II self-presentation. Trends Immunol (2003) 24(12):633-8. doi:10.1016/j.it.2003.10.010

109. LeGuern C, Shimada H, Emery DW, Germana S, Shafer GE, Sachs DH Retrovirus-mediated transfer of MHC class II cDNA into swine bone marrow cells. J Mol Med (Berl) (1995) 73(6):269-78. doi:10.1007/BF00231613

110. Germana S, Shimada H, Sachs DH, LeGuern C. Retroviral vectors transfer functional MHC class II heterodimers into bone marrow: a genetic approach to tolerance induction. Transplant Proc (1997) 29(1-2):1129. doi:10.1016/ S0041-1345(96)00463-0

111. Sonntag KC, Emery DW, Yasumoto A, Haller G, Germana S, Sablinski T, et al Tolerance to solid organ transplants through transfer of MHC class II genes. J Clin Invest (2001) 107(1):65-71. doi:10.1172/JCI11015

112. LeGuern C. Potential role of major histocompatibility complex class II peptides in regulatory tolerance to vascularized grafts. Transplantation (2004) 77(1 Suppl):S35-7. doi:10.1097/01.TP.0000106472.91343.8D

113. LeGuern C, Akiyama Y, Germana S, Tanaka K, Fernandez L, Iwamoto Y, et al. Intracellular MHC class II controls regulatory tolerance to allogeneic transplants. J Immunol (2010) 184(5):2394-400. doi:10.4049/jimmunol.0803664

114. Wing K, Sakaguchi S. Regulatory T cells exert checks and balances on self tolerance and autoimmunity. Nat Immunol (2010) 11(1):7-13. doi:10.1038/ ni. 1818

115. Ochando JC, Homma C, Yang Y, Hidalgo A, Garin A, Tacke F, et al. Alloantigen-presenting plasmacytoid dendritic cells mediate tolerance to vascularized grafts. Nat Immunol (2006) 7(6):652-62. doi:10.1038/ni1333

116. Ezzelarab M, Thomson AW. Tolerogenic dendritic cells and their role in transplantation. Semin Immunol (2011) 23(4):252-63. doi:10.1016/ j.smim.2011.06.007

117. McCurry KR, Colvin BL, Zahorchak AF, Thomson AW. Regulatory dendritic cell therapy in organ transplantation. Transpl Int (2006) 19(7):525-38. doi:10.1111/j.1432-2277.2006.00306.x

Conflict of Interest Statement: The authors declare that the research was conducted in the absence of any commercial or financial relationships that could be construed as a potential conflict of interest.

Copyright (C) 2016 Marino, Paster and Benichou. This is an open-access article distributed under the terms of the Creative Commons Attribution License (CC BY). The use, distribution or reproduction in other forums is permitted, provided the original author(s) or licensor are credited and that the original publication in this journal is cited, in accordance with accepted academic practice. No use, distribution or reproduction is permitted which does not comply with these terms. 